Published in final edited form as:

Organometallics. 2007 ; 26(8): 1907-1911.

\title{
Studies on the Condensation Pathway to and Properties of Diiron Azadithiolate Carbonyls
}

\author{
Jane L. Stanley, Thomas B. Rauchfuss ${ }^{*}$, and Scott R. Wilson \\ Department of Chemistry, University of Illinois at Urbana-Champaign, Urbana, Illinois 61801
}

\section{Abstract}

Reaction of $\mathrm{Fe}_{2}(\mathrm{SH})_{2}(\mathrm{CO})_{6}$ and $\mathrm{HCHO}$, which gives $\mathrm{Fe}_{2}\left[\left(\mathrm{SCH}_{2}\right)_{2} \mathrm{NH}\right](\mathrm{CO})_{6}$ in the presence of $\mathrm{NH}_{3}$, affords the possible intermediate $\mathrm{Fe}_{2}\left(\mathrm{SCH}_{2} \mathrm{OH}\right)_{2}(\mathrm{CO})_{6}$, which has been characterized crystallographically as its axial-equatorial isomer. $\mathrm{Fe}_{2}\left(\mathrm{SCH}_{2} \mathrm{OH}\right)_{2}(\mathrm{CO})_{6}$ was shown to react with ammonia and amines to give $\mathrm{Fe}_{2}\left[\left(\mathrm{SCH}_{2}\right)_{2} \mathrm{NR}\right](\mathrm{CO})_{6}(\mathrm{R}=\mathrm{H}$, alkyl). Related hemithioacetal intermediates were generated by treatment of $\mathrm{Fe}_{2}(\mathrm{SH})_{2}(\mathrm{CO})_{6}$ with $\mathrm{RC}(\mathrm{O}) \mathrm{C}(\mathrm{O}) \mathrm{R}(\mathrm{R}=\mathrm{H}, \mathrm{Ph}, 4-\mathrm{F}-$ $\left.\mathrm{C}_{6} \mathrm{H}_{4}\right)$ to give cycloadducts. The benzil derivative $\mathrm{Fe}_{2}\left[\mathrm{~S}_{2} \mathrm{C}_{2}(\mathrm{OH})_{2} \mathrm{Ph}_{2}\right](\mathrm{CO})_{6}$, a $C_{2}$-symmetric species, was also characterized crystallographically. The acylated azadithiolate $\mathrm{Fe}_{2}\left[\left(\mathrm{SCH}_{2}\right)_{2} \mathrm{NAc}\right]$ $(\mathrm{CO})_{6}$ was prepared by reaction of $\mathrm{Li}_{2} \mathrm{Fe}_{2} \mathrm{~S}_{2}(\mathrm{CO})_{6}$ with $\left(\mathrm{ClCH}_{2}\right)_{2} \mathrm{NC}(\mathrm{O}) \mathrm{Me}$. DNMR experiments show that the free energies of activation for rotation of the amide bond are the same for $\mathrm{Fe}_{2}\left[\left(\mathrm{SCH}_{2}\right)_{2} \mathrm{NAc}\right](\mathrm{CO})_{6}$ and $\mathrm{Fe}_{2}\left[\left(\mathrm{SCH}_{2}\right)_{2} \mathrm{NAc}\right](\mathrm{CO})_{4}\left(\mathrm{PMe}_{3}\right)_{2}$, which implies that the ligands on the iron centers do not strongly affect the basicity of the nitrogen. As a control, we showed that the thioamide $\mathrm{Fe}_{2}\left[\left(\mathrm{SCH}_{2}\right)_{2} \mathrm{NC}(\mathrm{S}) \mathrm{Me}\right](\mathrm{CO})_{6}$ does exhibit a significantly higher barrier to rotation, attributable to the increased double-bond character of the $\mathrm{N}-\mathrm{C}(\mathrm{S})$ bond.

\section{Introduction}

Since diiron azadithiolates were first reported in $2001,{ }^{1}$ many derivatives of the type $\mathrm{Fe}_{2}\left[\left(\mathrm{SCH}_{2}\right)_{2} \mathrm{NR}\right](\mathrm{CO})_{6}{ }_{\mathrm{x}}{ }_{\mathrm{L}} \mathrm{L}_{\mathrm{x}}$ have been described. ${ }^{1-5}$ These efforts are motivated by the following considerations: (i) the possibility that the azadithiolate is the dithiolate cofactor in the Fe-only hydrogenases, ${ }^{6}$ (ii) the possibility that such a ligand could play a functional role in the heterolytic activation of $\mathrm{H}_{2}, 7,8$ and (iii) the amine is a versatile point of attachment for diverse substituents. ${ }^{4,5}$ The functionalization of organometallic sulfides is an active area. ${ }^{9}$

Although many azadithiolato complexes have been described, relatively few studies have examined the parent $\mathrm{Fe}_{2}\left[\left(\mathrm{SCH}_{2}\right)_{2}-\mathrm{NH}\right](\mathrm{CO})_{6}(\mathbf{1 H}){ }^{3}$ This species contains the specific dithiolate that is plausible biologically. Compound $1 \mathrm{H}$ has been prepared by treatment of $\mathrm{Fe}_{2}(\mathrm{SH})_{2}(\mathrm{CO})_{6}$ with formaldehyde and sources of ammonia. Alternatively, $\mathbf{1 H}$ can be prepared by condensation of $\mathrm{Fe}_{2}(\mathrm{SH})_{2}(\mathrm{CO})_{6}$ with hexamethylenetetramine. ${ }^{3}$ These condensation pathways have been lightly studied, and proposed intermediates have not been well characterized. We previously proposed that formaldehyde adds to $\mathrm{Fe}_{2}(\mathrm{SH})_{2}(\mathrm{CO})_{6}$ to give hydroxymethyl intermediates that condense with amine or ammonia. In this paper we describe the isolation of such hydroxyalkyl derivatives. The formation of azadithiolates via the apparent condensation of hydroxymethyl amines with $\mathrm{Fe}_{2}(\mathrm{SH})_{2}(\mathrm{CO})_{6}$ has also been demonstrated. ${ }^{5}$

*To whom correspondence should be addressed. E-mail: Rauchfuz@uiuc.edu.

Supporting Information Available: Figures giving NMR spectra for the species synthesized in this study and CIF files giving crystallographic data for $\mathrm{Fe}_{2}\left(\mathrm{SCH}_{2} \mathrm{OH}\right)_{2}(\mathrm{CO})_{6}$ and $\mathrm{Fe}_{2}\left[\mathrm{~S}_{2} \mathrm{C}_{2}(\mathrm{OH})_{2}-\mathrm{Ph}_{2}\right](\mathrm{CO})_{6}$. This material is available free of charge via the Internet at http://pubs.acs.org. 
In this project we also sought to probe possible coupling of the azadithiolato functionality to the electronic properties of the attached diiron unit. We previously reported that $1 \mathrm{H}$ was only weakly basic, ${ }^{1}$ but we had not evaluated the character of the amine in derivatives where $\mathrm{CO}$ has been substituted. This aspect is biologically relevant, since in nature, the dithiolate is attached to a diiron center bound to two cyanide ligands, which are powerful $\sigma$-donors.

\section{Results}

\section{Synthesis and Basic Properties of $\mathrm{Fe}_{2}\left[\left(\mathrm{SCH}_{2}\right)_{2} \mathrm{NH}\right](\mathrm{CO})_{6}$}

Compound $1 \mathrm{H}$ was prepared by the addition of aqueous formaldehyde to a THF solution of $\mathrm{Fe}_{2}(\mathrm{SH})_{2}(\mathrm{CO})_{6},{ }^{10}$ followed by the addition of ammonium carbonate. Yields were ca. $25 \%$. The corresponding reaction of $\mathrm{Fe}_{2}(\mathrm{SH})_{2}(\mathrm{CO})_{6}, \mathrm{HCHO}$, and $t-\mathrm{BuNH}_{2}$ proceeded more efficiently to give $1 \mathrm{Bu}-t$ in $60 \%$ yield (Scheme 1). Qualitative tests demonstrated that $1 \mathrm{H}$ and 1Bu- $t$ are relatively stable to heat and air; therefore, the modest yields appear not to reflect instability intrinsic to the complex. Compound $1 \mathrm{Bu}-t$ was, however, decomposed by primary and secondary amines as well as by $\mathrm{H}_{2} \mathrm{~S}$. In contrast, the corresponding propanedithiolate $\mathrm{Fe}_{2}\left(\mathrm{~S}_{2} \mathrm{C}_{3} \mathrm{H}_{6}\right)(\mathrm{CO})_{6}$ is largely unaffected by $\mathrm{H}_{2} \mathrm{~S}$ and dilute solutions of amines. Ott et al. have shown that amines displace a $\mathrm{CO}$ ligand in $\mathrm{Fe}_{2}\left(\mathrm{~S}_{2} \mathrm{C}_{3} \mathrm{H}_{6}\right)-(\mathrm{CO})_{6}{ }^{5}$

\section{Characterization of $\mathrm{Fe}_{2}\left(\mathrm{SCH}_{2} \mathrm{OH}\right)_{2}(\mathrm{CO})_{6}$}

THF solutions of $\mathrm{Fe}_{2}(\mathrm{SH})_{2}(\mathrm{CO})_{6}$ react with 2 equiv of aqueous formaldehyde. Reaction progress can be monitored by in situ IR spectroscopy with a focus on the highest energy $v_{\mathrm{CO}}$ band. A major product is $\mathrm{Fe}_{2}\left(\mathrm{SCH}_{2} \mathrm{OH}\right)_{2}(\mathrm{CO})_{6}$, but mass spectra suggest that the reaction affords additional products such as $\mathrm{Fe}_{2}\left(\mathrm{SCH}_{2} \mathrm{OH}\right)-\left(\mathrm{SCH}_{2} \mathrm{OCH} \mathrm{H}_{2} \mathrm{OH}\right)(\mathrm{CO})_{6} \cdot{ }^{1} \mathrm{H}$ NMR spectra proved problematic, although we observed equally intense singlets at $\delta 4.6$ and 4.36, which are assigned to the axial-equatorial isomer, as is seen in other examples of $\mathrm{Fe}_{2}(\mathrm{SR})_{2}(\mathrm{CO})_{6}$. 11,12 Attempts to remove the solvent resulted in loss of $\mathrm{CH}_{2} \mathrm{O}$, affording $\mathrm{Fe}_{2} \mathrm{~S}_{2}(\mathrm{CO})_{6}$. Samples of $\mathrm{Fe}_{2}\left(\mathrm{SCH}_{2} \mathrm{OH}\right)_{2}(\mathrm{CO})_{6}$ were shown to react with ammonia and primary amines to give the azadithiolates $\mathrm{Fe}_{2}\left[\left(\mathrm{SCH}_{2}\right)_{2} \mathrm{NR}\right](\mathrm{CO})_{6}(\mathrm{R}=\mathrm{H}, \mathrm{Bu}-t)$.

Although $\mathrm{Fe}_{2}\left(\mathrm{SCH}_{2} \mathrm{OH}\right)_{2}(\mathrm{CO})_{6}$ was unstable, we were able to obtain single crystals from hexane (Figure 1, Table 1). Two independent but similar molecules comprise the asymmetric unit. The crystallographic analysis confirmed the previously anticipated ${ }^{3}$ structure, wherein hydroxymethyl groups adopt the axial-equatorial orientation. Otherwise, the structure is unremarkable and quite similar to that of $\mathrm{Fe}_{2}(\mathrm{SEt})_{2}(\mathrm{CO})_{6} .{ }^{12}$ The individual molecules are interconnected by hydrogen bonding.

\section{Condensation of $\mathrm{Fe}_{2}(\mathrm{SH})_{2}(\mathrm{CO})_{6}$ and Glyoxal}

In an effort to isolate a more stable aldehyde adduct, we treated $\mathrm{Fe}_{2}(\mathrm{SH})_{2}-(\mathrm{CO})_{6}$ with glyoxal, $(\mathrm{CHO})_{2}$. This condensation produced a red product, assumed to be $\mathrm{Fe}_{2}\left[\mathrm{~S}_{2}(\mathrm{CHOH})_{2}\right](\mathrm{CO})_{6}$, the polarity of which was evident from its low solubility in hexane. Its ${ }^{1} \mathrm{H}$ NMR spectrum exhibited three broadened signals, one of which is assigned to $\mathrm{OH}$ and the other two assigned to the $\mathrm{CH}$ on the meso and the chiral diastereoisomers, respectively. The IR spectrum of the mixture in the $v_{\mathrm{CO}}$ region was very similar to those for other $\mathrm{Fe}_{2}(\mathrm{SR})_{2}(\mathrm{CO})_{6}$ compounds. Careful chromatography produced samples that were enriched in one isomer, which isomerized over the course of several hours to the equilibrium mixture. We propose that the isomerization is associated with the reversibility of the aldehyde addition process. Consistent with this proposal, treatment of this isomeric mixture with aqueous formaldehyde and $t-\mathrm{BuNH}_{2}$ gave 1Bu- $t$ in good yield. 


\section{Condensation of $\mathrm{Fe}_{\mathbf{2}}(\mathrm{SH})_{2}(\mathrm{CO})_{6}$ with Benzil}

Treatment of $\mathrm{Fe}_{2}(\mathrm{SH})_{2}(\mathrm{CO})_{6}$ with benzil gave the yellow-brown adduct $\mathrm{Fe}_{2}-$ $\left[\mathrm{S}_{2} \mathrm{C}_{2}(\mathrm{OH})_{2} \mathrm{Ph}_{2}\right](\mathrm{CO})_{6}$ (eq 1). The reaction is slower than the addition of formaldehyde to $\mathrm{Fe}_{2}(\mathrm{SH})_{2}(\mathrm{CO})_{6}$, but the product proved more readily purified than other derivatives. The ${ }^{1} \mathrm{H}$ NMR spectrum of the product exhibited a $\mathrm{D}_{2} \mathrm{O}$-exchangeable signal at $\delta 2.83$. The compound also appears to be unstable in polar solvents such as $\mathrm{CD}_{3} \mathrm{CN}$ solution. We also spectroscopically characterized the corresponding adduct of 4,4'-difluorobenzil, $\mathrm{Fe}_{2}\left[\mathrm{~S}_{2} \mathrm{C}_{2}(\mathrm{OH})_{2}\left(\mathrm{C}_{6} \mathrm{H}_{4}-4-\mathrm{F}\right)_{2}\right]$ $(\mathrm{CO})_{6}$. The ${ }^{1} \mathrm{H}$ and ${ }^{19} \mathrm{~F}$ NMR spectra indicate that this compound is structurally analogous to the benzil derivative.

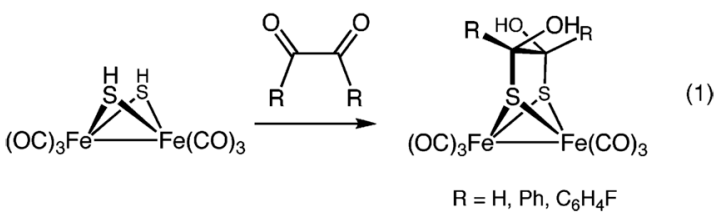

The structure $\mathrm{Fe}_{2}\left[\mathrm{~S}_{2} \mathrm{C}_{2}(\mathrm{OH})_{2} \mathrm{Ph}_{2}\right](\mathrm{CO})_{6}$ was examined by single-crystal X-ray diffraction (Figure 2, Table 2). The molecule consists of the usual $\mathrm{Fe}_{2} \mathrm{~S}_{2}$ butterfly core with idealized $\mathrm{C}_{2}$ symmetry. The hydroxyl groups, the $\mathrm{H}$ atoms of which were refined, are mutually trans. The $\mathrm{S}_{2} \mathrm{C}_{2}$ ligand backbone is twisted as a result of the steric influence of the $\mathrm{Ph}$ groups. The protons of the $\mathrm{CO}-\mathrm{H}$ groups are oriented toward the $\mathrm{CO}$ ligand, but any interaction between the $\mathrm{OH}$ groups and the axial $\mathrm{CO}$ ligands must be weak because the $v_{\mathrm{CO}}$ bands in the IR spectrum are unremarkable. The IR spectrum of this compound in solution is almost identical with that for $\mathrm{Fe}_{2}\left(\mathrm{~S}_{2} \mathrm{C}_{2} \mathrm{H}_{4}\right)(\mathrm{CO})_{6}$. The IR spectrum of a $\mathrm{KBr}$ pellet containing the compound displayed six sharp $v_{\mathrm{CO}}$ bands, consistent with its low symmetry.

\section{Acylated Derivatives of $\mathrm{Fe}_{2}\left[\left(\mathrm{SCH}_{2}\right)_{2} \mathrm{NH}\right](\mathrm{CO})_{6}$}

The complex $\mathrm{Fe}_{2}\left[\left(\mathrm{SCH}_{2}\right)_{2} \mathrm{NC}(\mathrm{O}) \mathrm{Me}\right](\mathrm{CO})_{6}(\mathbf{1} \mathrm{Ac})$ was initially prepared by the condensation of $\mathrm{MeC}(\mathrm{O}) \mathrm{NH}_{2}$ and $\mathrm{Fe}_{2}\left(\mathrm{SCH}_{2} \mathrm{OH}\right)_{2}(\mathrm{CO})_{6}$. FD-MS and NMR confirmed the formation of $1 \mathrm{Ac}$, but the reproducibility and yield were poor. More successful was the alkylation of $\mathrm{Li}_{2} \mathrm{Fe}_{2} \mathrm{~S}_{2}(\mathrm{CO})_{6}$ with $\left(\mathrm{ClCH}_{2}\right)_{2} \mathrm{NAc} .{ }^{13}$ We tested the possible conversion of $\mathbf{1 A c}$ into $\mathbf{1 H}$, but $1 \mathrm{Ac}$ was stable in hot $\left(55^{\circ} \mathrm{C}\right) 12 \mathrm{M} \mathrm{HCl}$. Thiation of $1 \mathrm{Ac}$ with Lawesson's reagent ${ }^{14}$ afforded the expected thioamide $\mathrm{Fe}_{2}\left[\left(\mathrm{SCH}_{2}\right)_{2} \mathrm{NC}(\mathrm{S}) \mathrm{Me}\right](\mathrm{CO})_{6}$. The IR spectra of the amide and thioamide were virtually indistinguishable in the $v_{\mathrm{MCO}}$ region. We found that $1 \mathrm{Ac}$ reacted with $\mathrm{PMe}_{3}$ to give $\mathrm{Fe}_{2}\left[\left(\mathrm{SCH}_{2}\right)_{2} \mathrm{NAc}\right](\mathrm{CO})_{4}\left(\mathrm{PMe}_{3}\right)_{2}$, which was characterized spectroscopically.

\section{DNMR Studies of $\mathrm{Fe}_{2}\left[\left(\mathrm{SCH}_{2}\right)_{2} \mathrm{NC}(\mathrm{X}) \mathrm{Me}\right](\mathrm{CO})_{6}(\mathrm{X}=\mathrm{S}, \mathrm{O})$}

The ${ }^{1} \mathrm{H}$ NMR spectrum of $\mathbf{1 A c}$ was examined over the range -80 to $+100{ }^{\circ} \mathrm{C}$. Only one methyl signal was observed at all temperatures, which indicates the absence of isomers. The signals for the methylene groups, however, changed significantly as a function of temperature (Figure 3). At $-80^{\circ} \mathrm{C}$, two doublets of doublets for $\mathrm{SCH}_{2} \mathrm{~N}$ were observed. When the sample was warmed, these signals broadened, coalescing into two singlets at room temperature. At $\sim 100$ ${ }^{\circ} \mathrm{C}$ in $\mathrm{CD}_{3} \mathrm{C}_{6} \mathrm{D}_{5}$ solution, the two $\mathrm{CH}_{2}$ singlets coalesced into a broad singlet. Two dynamic processes are relevant to these observations. First, the "flipping" of the $\mathrm{FeS}_{2} \mathrm{C}_{2} \mathrm{~N}$ ring, which is seen also for $\mathrm{Fe}_{2}(\mathrm{pdt})(\mathrm{CO})_{6}$ and $\mathbf{1 H}$, has a low barrier of ca. $10 \mathrm{kcal} / \mathrm{mol} .{ }^{15}$ More interesting is the rotation about the $\mathrm{N}-\mathrm{C}(\mathrm{O})$ bond, which has a high barrier. For acetamide, the barrier is ca. $18 \mathrm{kcal} / \mathrm{mol}^{16}$

The DNMR spectrum for $\mathrm{Fe}_{2}\left[\left(\mathrm{SCH}_{2}\right)_{2} \mathrm{NAc}\right](\mathrm{CO})_{4}\left(\mathrm{PMe}_{3}\right)_{2}$ was similar to that for the hexacarbonyl parent. In particular, the coalescence temperatures for $\mathrm{Fe}_{2}\left[\left(\mathrm{SCH}_{2}\right)_{2} \mathrm{NAc}\right]$ $(\mathrm{CO})_{4}\left(\mathrm{PMe}_{3}\right)_{2}$ and $\mathrm{Fe}_{2}\left[\left(\mathrm{SCH}_{2}\right)_{2} \mathrm{NAc}\right](\mathrm{CO})_{6}$ are nearly identical, which is significant because 
for each compound the $\Delta \delta$ values for the two $\mathrm{CH}_{2}$ singlets are within $10 \%$. This observation suggests that the donor ligand does not affect the $\mathrm{N}-\mathrm{C}(\mathrm{O}) \pi$-bond. As a control experiment, we evaluated the DNMR properties of $\mathrm{Fe}_{2}\left[\left(\mathrm{SCH}_{2}\right)_{2} \mathrm{NC}(\mathrm{S}) \mathrm{Me}\right](\mathrm{CO})_{6}$. The overall pattern for the low-temperature chemical shifts are similar to those for the parent amide, although rotation about the $\mathrm{N}-\mathrm{C}(\mathrm{S}) \mathrm{Me}$ bond is subject to a higher barrier, as coalescence is $>100^{\circ} \mathrm{C}$.

\section{Discussion}

The condensation route from $\mathrm{Fe}_{2}(\mathrm{SH})_{2}(\mathrm{CO})_{6}$ to $\mathrm{Fe}_{2}\left[\left(\mathrm{SCH}_{2}\right)_{2}-\mathrm{NH}\right](\mathrm{CO})_{6}$ was shown to be consistent with the intermediacy of hydroxymethyl derivatives. The reactivity of MSH complexes toward aldehydes has been previously discussed only lightly, although the reaction of thiols with aldehydes is well-known in organic chemistry and biochemistry. ${ }^{17}$ The compounds $\mathrm{Fe}_{2}\left(\mathrm{SCH}_{2}-\mathrm{OH}\right)_{2}(\mathrm{CO})_{6}$ and $\mathrm{Fe}_{2}\left[\mathrm{~S}_{2} \mathrm{C}_{2}(\mathrm{OH})_{2} \mathrm{Ph}_{2}\right](\mathrm{CO})_{6}$ are rare structurally characterized examples of the $\mathrm{M}-\mathrm{SCR}_{2} \mathrm{OH}$ functionality. Among complexes containing the M-SCR $2 \mathrm{OH}$ linkage, the unstable species $\mathrm{Fe}_{2}\left(\mathrm{SCMe}_{2} \mathrm{CH}_{2} \mathrm{C}(\mathrm{OH})(\mathrm{Me}) \mathrm{S}\right)(\mathrm{CO})_{6}$ was previously generated via the addition of $\mathrm{Fe}_{2}(\mathrm{SH})_{2}(\mathrm{CO})_{6}$ to the $\alpha, \beta$-unsaturated ketone $\mathrm{Me}_{2} \mathrm{C}=\mathrm{CHC}(\mathrm{O})$ Me. ${ }^{18}$ Another example of this functionality resulted from the addition of hydroxide to $\eta^{5}$ thiophene complexes. 19

The dynamics for $\mathrm{Fe}_{2}\left[\left(\mathrm{SCH}_{2}\right)_{2} \mathrm{NAc}\right](\mathrm{CO})_{6}$ and $\mathrm{Fe}_{2}\left[\left(\mathrm{SCH}_{2}\right)_{2}-\mathrm{NAc}\right](\mathrm{CO})_{4}\left(\mathrm{PMe}_{3}\right)_{2}$ proved to be similar. This observation indicates that donor ligands on Fe do not substantially influence the nitrogen of the azadithiolate ligand. This finding in turn suggests that the ligands on the diiron subunit do not strongly interact with the nitrogen of the azadithiolate. Consistent with this observation, we observe that $v_{\mathrm{CO}}$ varies little as one changes the substituents on nitrogen from $\mathrm{H}$ to Ac.

\section{Experimental Section}

Unless otherwise indicated, reactions were conducted using Schlenk techniques at room temperature. ${ }^{1} \mathrm{H}$ and ${ }^{31} \mathrm{P}$ NMR spectra were recorded on an $11.7 \mathrm{~T}$ instrument. IR data are reported in $\mathrm{cm}^{-1}$. Chromatography was conducted in air. Other methods used in this laboratory have been recently described. 20

\section{Revised Preparation of $\mathrm{Fe}_{2} \mathrm{~S}_{2}(\mathrm{CO})_{6}$}

The following procedure represents a further optimization of the literature method. ${ }^{21} \mathrm{~A}$ threeneck, $2 \mathrm{~L}$ round-bottomed flask was fitted with a mechanical stirrer, a $\mathrm{N}_{2}$-inlet adapter, and a septum connected to a bubbler. After being flushed with $\mathrm{N}_{2}$, the flask was charged with $50 \mathrm{~mL}$ $(0.378 \mathrm{~mol})$ of $\mathrm{Fe}(\mathrm{CO})_{5}$, followed by $250 \mathrm{~mL}$ of $\mathrm{MeOH}$, and finally $150 \mathrm{~mL}$ of freshly prepared aqueous $\mathrm{KOH}(\sim 50 \%)$. After it was stirred for $30 \mathrm{~min}$, the homogeneous solution was cooled to $0{ }^{\circ} \mathrm{C}$, and $65.33 \mathrm{~g}$ of $\mathrm{S}_{8}$ was delivered over the course of $5 \mathrm{~min}$. The turbid black mixture was stirred for $1 \mathrm{~h}$ and then was treated with $625 \mathrm{~mL}$ of $\mathrm{H}_{2} \mathrm{O}, 1500 \mathrm{~mL}$ of pentane (or hexanes), and finally $169 \mathrm{~g}(3.16 \mathrm{~mol})$ of $\mathrm{NH}_{4} \mathrm{Cl}$. Caution! Evolution of $\mathrm{H}_{2} \mathrm{~S}$. The ice bath was then removed, and the reaction mixture was stirred at room temperature for 14-16 h, after which time bubbling had slowed significantly. The resulting reaction mixture consisted of a dark red pentane layer and a black oily aqueous phase. The pentane layer was filtered through a pad of ca. $400 \mathrm{~mL}$ of Celite, which was then rinsed with ca. $500 \mathrm{~mL}$ of pentane. The oily aqueous phase was extracted with 1-2 $\mathrm{L}$ of pentane until all of the extracts were no longer red, and this pentane extract was also passed through the Celite. The combined deep red pentane fractions were washed with an approximately equal volume of water, dried over $\mathrm{Na}_{2} \mathrm{SO}_{4}$, and evaporated. The solid residue was then transferred to a $150 \mathrm{~mL}$ Schlenk flask fitted with a water-cooled cold finger sublimation apparatus. Sublimation was conducted at room temperature with a static vacuum maintained at ca. $0.01 \mathrm{mmHg}$. The red sublimate was periodically removed. The sublimation requires days for completion, but attempts to accelerate 
the process by warming the sample resulted in decreased yields. Yield: $30 \mathrm{~g} \mathrm{(46 \%} \mathrm{based} \mathrm{on} \mathrm{Fe}$ (CO) $)_{5}$ ). IR (cyclohexane): $v_{\mathrm{CO}} 2083$ (m), 2043 (s), 2007 (m), 1991 (m), 1969 (w), 1956 (w).

\section{$\mathrm{Fe}_{2}\left[\left(\mathrm{SCH}_{2}\right)_{2} \mathrm{NH}\right](\mathrm{CO})_{6}(1 \mathrm{H})$}

(a) Aminomethylation Reagent-In a $150 \mathrm{~mL}$ flask, a slurry of $2.23 \mathrm{~g} \mathrm{(3.09} \mathrm{mmol)} \mathrm{of}$ $\left(\mathrm{NH}_{4}\right)_{2} \mathrm{CO}_{3}$ in $30 \mathrm{~mL}$ of THF was warmed to $60{ }^{\circ} \mathrm{C}$ and then treated over the course of $5 \mathrm{~min}$ with $25 \mathrm{~mL}$ ( $30.8 \mathrm{mmol})$ of $37 \%$ aqueous $\mathrm{HCHO}$, resulting in a colorless solution. Following the addition, the solution was heated at $60^{\circ} \mathrm{C}$ for $1 \mathrm{~h}$ and then cooled to room temperature.

(b) $\mathrm{Fe}_{2}\left[\left(\mathrm{SCH}_{2}\right)_{2} \mathrm{NH}\right](\mathrm{CO})_{6}$ - In an adaptation of the procedure of Seyferth, a solution of 1.07 $\mathrm{g}(3.11 \mathrm{mmol})$ of $\mathrm{Fe}_{2} \mathrm{~S}_{2}(\mathrm{CO})_{6}$ in $20 \mathrm{~mL}$ of THF, cooled to $-78{ }^{\circ} \mathrm{C}$, was treated with $7.0 \mathrm{~mL}$ (7.0 mmol) of a $1.0 \mathrm{M}$ THF solution of $\mathrm{LiEt}_{3} \mathrm{BH}$. After $15 \mathrm{~min}, 1.0 \mathrm{~mL}(12.9 \mathrm{mmol})$ of $\mathrm{CF}_{3} \mathrm{CO}_{2} \mathrm{H}$ was added to give a red-orange solution. After a further $15 \mathrm{~min}$, the reaction solution was warmed to room temperature. The entire aminomethylation solution was transferred dropwise via cannula into the $\mathrm{Fe}_{2}(\mathrm{SH})_{2}(\mathrm{CO})_{6}$ solution over the course of $15 \mathrm{~min}$. After it was stirred for 16-20 h, the brown-red solution was evaporated, and the brown oily solid was extracted into ca. $200 \mathrm{~mL}$ of hexanes with vigorous stirring and sonication. The extracts were filtered and evaporated to dryness. The residue was then extracted into $8 \mathrm{~mL}$ of hexanes and chromatographed on a $4 \times 30 \mathrm{~cm}$ silica gel column. Elution with hexanes gave three bands in the following order: unreacted $\mathrm{Fe}_{2} \mathrm{~S}_{2}(\mathrm{CO})_{6}(50-100 \mathrm{mg})$, an unidentified red oil, and the product. Yield: $0.49 \mathrm{~g}$ (44\%). IR (hexanes): $v_{\mathrm{CO}} 2075$ (m), 2035 (s), 2007 (s), 1989 (s), 1979 (s).

\section{$\mathrm{Fe}_{2}\left(\mathrm{SCH}_{2} \mathrm{OH}\right)_{2}(\mathrm{CO})_{6}$}

By the procedure as outlined above, $\mathrm{Fe}_{2}-(\mathrm{SH})_{2}(\mathrm{CO})_{6}(1.46 \mathrm{mmol})$ was generated in situ at -78 ${ }^{\circ} \mathrm{C}$ from $0.502 \mathrm{~g}(1.46 \mathrm{mmol})$ of $\mathrm{Fe}_{2} \mathrm{~S}_{2}(\mathrm{CO})_{6}$ in $20 \mathrm{~mL}$ of THF, $3.2 \mathrm{~mL}$ of a $1.0 \mathrm{M}$ THF solution of $\mathrm{LiEt}_{3} \mathrm{BH}$, and $0.40 \mathrm{~mL}(5.19 \mathrm{mmol})$ of $\mathrm{CF}_{3} \mathrm{CO}_{2} \mathrm{H}$. The cold reaction mixture was treated with $0.24 \mathrm{~mL}(2.96 \mathrm{mmol})$ of $37 \%$ aqueous $\mathrm{CH}_{2} \mathrm{O}$, and the reaction solution was then warmed to room temperature. After the reaction mixture was stirred for ca. $16 \mathrm{~h}$, solvent was removed, leaving a deep red oil that was washed with $10 \mathrm{~mL}$ of hexanes to remove unreacted $\mathrm{Fe}_{2} \mathrm{~S}_{2^{-}}$ $(\mathrm{CO})_{6}$. The red oil was extracted into $5 \mathrm{~mL}$ of $\mathrm{Et}_{2} \mathrm{O}$, and this solution was diluted with $50 \mathrm{~mL}$ of hexanes to precipitate colorless solids. The filtrate was evaporated to dryness, and the extraction-precipitation procedure was repeated. The orange-red $\mathrm{Fe}_{2}\left(\mathrm{SCH}_{2} \mathrm{OH}\right)_{2}-(\mathrm{CO})_{6}$ was finally extracted into $20 \mathrm{~mL}$ of hexanes, and this solution was filtered. When the filtrate was allowed to stand at room temperature, crystals appeared. FD-MS $(\mathrm{m} / \mathrm{z}): 343.8\left(\mathrm{Fe}_{2} \mathrm{~S}_{2}(\mathrm{CO})_{6}\right.$, $15 \%), 376\left(\mathrm{Fe}_{2}(\mathrm{SH})\left(\mathrm{SCH}_{2} \mathrm{OH}\right)(\mathrm{CO})_{6}, 50 \%\right), 406\left(\mathrm{Fe}_{2}\left(\mathrm{SCH}_{2} \mathrm{OH}\right)_{2}-(\mathrm{CO})_{6}, 100 \%\right), 436$ $\left(\mathrm{Fe}_{2}\left(\mathrm{SCH}_{2} \mathrm{OH}\right)\left(\mathrm{SCH}_{2} \mathrm{OCH}_{2} \mathrm{OH}\right)(\mathrm{CO})_{6}, 10 \%\right)$. IR (THF): $v_{\mathrm{CO}} 2071(\mathrm{w}), 2034(\mathrm{~s}), 1994(\mathrm{~m})$.

\section{$\mathrm{Fe}_{2}\left[\left(\mathrm{SCH}_{2}\right)_{2} \mathrm{NBu}-t\right](\mathrm{CO})_{6}(1 \mathrm{Bu}-t)$}

A solution of $\mathrm{Fe}_{2}(\mathrm{SH})_{2}(\mathrm{CO})_{6}$ was first generated from $0.215 \mathrm{~g}(0.624 \mathrm{mmol})$ of $\mathrm{Fe}_{2} \mathrm{~S}_{2}(\mathrm{CO})_{6}$ in $10 \mathrm{~mL}$ of THF, $1.26 \mathrm{~mL}$ (1.26 mmol) of $1.0 \mathrm{M} \mathrm{LiEt}_{3} \mathrm{BH}$ in THF, and $0.13 \mathrm{~mL}(1.69 \mathrm{mmol})$ of $\mathrm{CF}_{3} \mathrm{CO}_{2} \mathrm{H}$. This solution was treated with $0.10 \mathrm{~mL}(1.23 \mathrm{mmol})$ of $37 \%$ aqueous $\mathrm{CH}_{2} \mathrm{O}$, and after ca. $1 \mathrm{~h}$, the reaction solution was treated with $0.07 \mathrm{~mL}(0.66 \mathrm{mmol})$ of $t-\mathrm{BuNH}_{2}$, causing the red solution to deepen in color. After $20 \mathrm{~min}$, the solvent was removed, and the residue was extracted with $\sim 30 \mathrm{~mL}$ of hexanes. The extracts were concentrated to $\sim 5 \mathrm{~mL}$ and chromatographed on a $4 \times 30 \mathrm{~cm}$ silica gel column. Elution with hexanes gave unreacted $\mathrm{Fe}_{2} \mathrm{~S}_{2}(\mathrm{CO})_{6}(23 \mathrm{mg})$ and $\mathrm{Fe}_{2}\left[\left(\mathrm{SCH}_{2}\right)_{2} \mathrm{NBut}\right](\mathrm{CO})_{6}$. Yield: $0.144 \mathrm{~g}$ (52\%; $58 \%$ conversion). IR (hexanes): $v_{\mathrm{CO}} 2074$ (m), 2036 (s), 2003 (s), 1995 (s), 1982 (m). ${ }^{1} \mathrm{H}_{\mathrm{NMR}}\left(\mathrm{CD}_{3}-\mathrm{CN}\right): \delta 3.30$ (br, $\left.4 \mathrm{H}, \mathrm{CH}_{2}\right), 0.98\left(\mathrm{~s}, 9 \mathrm{H}, \mathrm{CH}_{3}\right)$. 


\section{$\mathrm{Fe}_{2}\left[\mathrm{~S}_{2}(\mathrm{CHOH})_{2}\right](\mathrm{CO})_{6}$}

A solution of $0.18 \mathrm{~g}(0.52 \mathrm{mmol})$ of $\mathrm{Fe}_{2}(\mathrm{SH})_{2}(\mathrm{CO})_{6}$ in $20 \mathrm{~mL}$ of THF was treated with $1.0 \mathrm{~mL}$ of $40 \%$ aqueous (w/w) glyoxal. After this reaction mixture was stirred overnight, the solvent was evaporated, leaving a red oily residue. The residue was washed with $10 \mathrm{~mL}$ of hexane and then extracted with $5 \mathrm{~mL}$ of $\mathrm{CH}_{2} \mathrm{Cl}_{2}$. The extract was chromatographed on silica gel with $\mathrm{CH}_{2} \mathrm{Cl}_{2}$, and a red band consisting of a mixture of cis and trans isomers was obtained. Yield: $0.13 \mathrm{~g}(60 \%) .{ }^{1} \mathrm{H}$ NMR $\left(\mathrm{CD}_{3}-\mathrm{CN}\right): \delta 4.91$ (s, $2 \mathrm{H}, \mathrm{CH}$, trans), 4.82 (s, $2 \mathrm{H}, \mathrm{CH}$, cis), 4.63 (b, $2 \mathrm{H}, \mathrm{OH}$, cis and trans). IR $\left(\mathrm{CH}_{3} \mathrm{CN}\right): 3633,3540,2077,2040,1999$. HR-EIMS $(\mathrm{m} / \mathrm{z})$ : found (calcd) 403.804413 (403.804 639). Anal. Found (calcd): C, 24.30 (23.79); H, 1.07 (1.00). When this mixture was carefully rechromatographed on silica gel, initially with $2: 1 \mathrm{CH}_{2} \mathrm{Cl}_{2}-$ hexane and then pure $\mathrm{CH}_{2} \mathrm{Cl}_{2}$ as eluent, fractions enriched in trans isomer and cis isomer could be obtained. A solution of the two enriched isomers in $\mathrm{CH}_{3} \mathrm{CN}$ solution was observed to equilibrate in $7 \mathrm{~h}$ (for enriched cis isomer).

\section{$\mathrm{Fe}_{2}\left[\mathrm{~S}_{2} \mathrm{C}_{2}(\mathrm{OH})_{2} \mathrm{Ph}_{2}\right](\mathrm{CO})_{6}$}

A solution of $\mathrm{Fe}_{2}(\mathrm{SH})_{2}(\mathrm{CO})_{6}$ was generated in situ from $0.498 \mathrm{~g}(1.45 \mathrm{mmol})$ of $\mathrm{Fe}_{2} \mathrm{~S}_{2}(\mathrm{CO})_{6}, 15 \mathrm{~mL}$ of THF, $3.0 \mathrm{~mL}$ ( $3 \mathrm{mmol}$ ) of a $1.0 \mathrm{M}$ THF solution of $\mathrm{LiEt}_{3} \mathrm{BH}$, and 0.23 $\mathrm{mL}(2.99 \mathrm{mmol})$ of $\mathrm{CF}_{3} \mathrm{CO}_{2} \mathrm{H}$. This solution was treated with a solution of $0.304 \mathrm{~g}(1.45 \mathrm{mmol})$ of benzil in $5 \mathrm{~mL}$ of THF at $-78{ }^{\circ} \mathrm{C}$. After $1 \mathrm{~h}$, the cold bath was removed, and stirring was continued at room temperature for $\sim 14 \mathrm{~h}$ before solvent was removed from the deep yellowbrown solution using a hot water bath. While still warm, the dark brown oily residue was washed with ca. $40 \mathrm{~mL}$ of hexanes. The combined hexane extracts were filtered through Celite and reduced in volume by half, whereupon a mustard yellow solid precipitated. The solid was washed with ca. $35 \mathrm{~mL}$ of hexanes. When they were cooled to $0{ }^{\circ} \mathrm{C}$, the combined hexane extracts afforded crystals. Yield: $0.2 \mathrm{~g}(24 \%)$. The sample decomposed at $139{ }^{\circ} \mathrm{C} .{ }^{1} \mathrm{H}$ NMR $\left(\mathrm{CD}_{2} \mathrm{Cl}_{2}\right): 7.36$ (m, $\left.\mathrm{C}_{6} H_{5}\right), 2.83$ (s, OH). Anal. Found (calcd): C, 42.98 (43.19); H, 1.94 (2.17); N, 0.09 (0.00). IR (hexanes): $v_{\mathrm{CO}} 2077$ (m), 2041 (s), 2006 (m), 2002 (sh). IR (THF): $v_{\mathrm{OH}} 3577$ (w), $3509(\mathrm{w}) \mathrm{cm}^{-1} ; v_{\mathrm{CO}} 2071(\mathrm{~s}), 2035$ (s), and 1996 (s) $\mathrm{cm}^{-1}$. IR (KBr): $v_{\mathrm{OH}} 3503 \mathrm{~cm}^{-1}$; $v_{\mathrm{CO}} 2087(\mathrm{~m}), 2035$ (s), 2015 (s), 1999 (s), 1990 (s), 1978 (s) cm ${ }^{-1}$. FD-MS: $556\left(\mathrm{M}^{+}\right)$.

\section{$\mathrm{Fe}_{2}\left[\mathrm{~S}_{2} \mathrm{C}_{2}(\mathrm{OH})_{2}\left(\mathrm{C}_{6} \mathrm{H}_{4}-4-\mathrm{F}\right)_{2}\right](\mathrm{CO})_{6}$}

The preceding procedure, but using 4,4'-difluorobenzil in place of benzil, afforded an orangeyellow hygroscopic powder. Yield: $0.24 \mathrm{~g}(47 \%) .{ }^{1} \mathrm{H} N M R\left(\mathrm{CD}_{2}-\mathrm{Cl}_{2}\right): \delta 7.33(\mathrm{t}, 4 \mathrm{H}, o-$ $\left.\mathrm{C}_{6} \mathrm{H}_{4}-4-\mathrm{F}\right), 7.04$ (t, $\left.4 \mathrm{H}, m-\mathrm{C}_{6} H_{4}-4-\mathrm{F}\right), 2.89$ (s, 2H, OH). ${ }^{19} \mathrm{~F} \mathrm{NMR}\left(\mathrm{CD}_{2} \mathrm{Cl}_{2}\right)$ : $\delta-114$ (s). IR $\left(\mathrm{CH}_{2} \mathrm{Cl}_{2}\right): v_{\mathrm{CO}} 2077(\mathrm{~m}), 2041(\mathrm{~s}), 2003(\mathrm{~b}, \mathrm{~m}) \mathrm{cm}^{-1} ; v_{\mathrm{OH}} 3683(\mathrm{w}), 3530(\mathrm{w}) \mathrm{cm}^{-1}$. FD-MS: $592\left(\mathrm{M}^{+}\right)$.

\section{$\mathrm{Fe}_{2}\left[\left(\mathrm{SCH}_{2}\right)_{2} \mathrm{NAc}\right](\mathrm{CO})_{6}(1 \mathrm{Ac})$}

A solution of $\mathrm{Li}_{2} \mathrm{Fe}_{2} \mathrm{~S}_{2}(\mathrm{CO})_{6}$ in ca. $45 \mathrm{~mL}$ of THF was treated with $1.2 \mathrm{~mL}(10.9 \mathrm{mmol})$ of AcN- $\left(\mathrm{CH}_{2} \mathrm{Cl}\right)_{2}$. The reaction mixture was maintained at $-78^{\circ} \mathrm{C}$ for $1 \mathrm{~h}$ before being warmed to room temperature, at which point stirring was continued for $4 \mathrm{~h}$ before the solvent was removed. The dark brown-red oil was washed with $10 \mathrm{~mL}$ of hexanes and extracted with ca. $50 \mathrm{~mL}$ of $\mathrm{CH}_{2} \mathrm{Cl}_{2}$. The extract was filtered through Celite, concentrated, and chromatographed, with $\mathrm{CH}_{2} \mathrm{Cl}_{2}$ as eluent. The deep red second band was evaporated, and the resulting orangered oil was triturated with hexanes to give a dark orange solid. Yield: $1.43 \mathrm{~g} \mathrm{(38 \% ).} \mathrm{Mp:} 121$ ${ }^{\circ} \mathrm{C}$ dec. IR $\left(\mathrm{CH}_{2} \mathrm{Cl}_{2}\right): v_{\mathrm{CO}} 2078(\mathrm{~m}), 2040(\mathrm{~s}), 2006(\mathrm{~m}), 1999(\mathrm{sh}), 1669(\mathrm{~m}) \mathrm{cm}^{-1} .{ }^{1} \mathrm{H}$ NMR $\left(\mathrm{CD}_{3}-\mathrm{CN}\right): \delta 4.16\left(\mathrm{bs}, 2 \mathrm{H}, \mathrm{CH}_{2}\right), 4.14\left(\mathrm{~s}, 2 \mathrm{H}, \mathrm{CH}_{2}\right), 2.06\left(\mathrm{~s}, 3 \mathrm{H}, \mathrm{CH}_{3}\right) .{ }^{1} \mathrm{H}$ NMR (toluene$\left.d_{8}\right): \delta 3.57$ (bs, $\left.2 \mathrm{H}, \mathrm{CH}_{2}\right), 3.00\left(\mathrm{~s}, 2 \mathrm{H}, \mathrm{CH}_{2}\right), 1.43\left(\mathrm{~s}, 3 \mathrm{H}, \mathrm{CH}_{3}\right)$. FD-MS $(\mathrm{m} / \mathrm{z}): 428.9\left(\mathrm{M}^{+}\right)$. Anal. Found (calcd): C, 27.94 (28.00); H, 1.55 (1.65); N, 3.20 (3.27) 


\section{$\mathrm{Fe}_{2}\left[\left(\mathrm{SCH}_{2}\right)_{2} \mathrm{NC}(\mathrm{S}) \mathrm{Me}\right](\mathrm{CO})_{6}$}

A solution of $0.504 \mathrm{~g}(1.17 \mathrm{mmol})$ of $\mathrm{Fe}_{2}\left[\left(\mathrm{SCH}_{2}\right)_{2} \mathrm{NAc}\right](\mathrm{CO})_{6}$ in $15 \mathrm{~mL}$ of THF was treated with a slurry of $1.91 \mathrm{~g}(4.71 \mathrm{mmol})$ of Lawesson's reagent in $35 \mathrm{~mL}$ of THF. The reaction mixture was heated to reflux and monitored by TLC $\left(\mathrm{CH}_{2} \mathrm{Cl}_{2}\right)$ until conversion was complete. After ca. $19 \mathrm{~h}$ of reflux, solvent was removed from the cooled reaction mixture, and the resulting brown solid was chromatographed on silica gel, with $\mathrm{CH}_{2} \mathrm{Cl}_{2}$ as eluent. The dark red band was concentrated to leave a dark orange solid that was washed with hexanes. Yield: $0.45 \mathrm{~g} \mathrm{(85 \% ).}$ Upon attempted measurement of its melting point, the sample decomposed at $140{ }^{\circ} \mathrm{C}$. IR $\left(\mathrm{CH}_{2} \mathrm{Cl}_{2}\right): v_{\mathrm{CO}} 2080,2042,2008 \mathrm{~cm}^{-1} ; v_{\mathrm{C}=\mathrm{S}} 1121 \mathrm{~cm}^{-1}$. IR (hexanes): $v_{\mathrm{CO}} 2080,2043,2012$, 2005, $1988 \mathrm{~cm}^{-1} .{ }^{1} \mathrm{H}$ NMR $\left(\mathrm{CD}_{3} \mathrm{CN}\right): \delta 4.79$ (bs, $\left.\mathrm{CH}_{2}\right), 4.40\left(\mathrm{~s}, \mathrm{CH}_{2}\right), 2.59\left(\mathrm{~s}, \mathrm{CH}_{3}\right) .{ }^{1} \mathrm{H}$ NMR (toluene- $d_{8}$ ): $\delta 4.14$ (bs, $\left.\mathrm{CH}_{2}\right), 3.10\left(\mathrm{~s}, \mathrm{CH}_{2}\right), 1.98\left(\mathrm{~s}, \mathrm{CH}_{3}\right)$. FD-MS $(\mathrm{m} / \mathrm{z}): 445\left(\mathrm{M}_{+}\right)$. Anal. Found (calcd): C, 27.26 (26.99); H, 1.34 (1.59); N, 2.91 (3.15).

\section{$\mathrm{Fe}_{2}\left[\left(\mathrm{SCH}_{2}\right)_{2} \mathrm{NC}(\mathrm{O}) \mathrm{Me}\right](\mathrm{CO})_{4}\left(\mathrm{PMe}_{3}\right)_{2}$}

A solution of $0.199 \mathrm{~g}(0.463 \mathrm{mmol})$ of $\mathrm{Fe}_{2}\left[\left(\mathrm{SCH}_{2}\right)_{2} \mathrm{NAc}\right](\mathrm{CO})_{6}$ in $5 \mathrm{~mL}$ of toluene was treated with $0.55 \mathrm{~mL}(5.41 \mathrm{mmol})$ of $\mathrm{PMe}_{3}$ in $10 \mathrm{~mL}$ of toluene and heated to reflux. After it was refluxed for $1.5 \mathrm{~h}$, the cherry red solution was cooled to room temperature and filtered, and the solvent was removed to give a dark red oil. Trituration with hexanes gave the dark red solid. Yield: $0.177 \mathrm{~g}(73 \%)$. IR (toluene): $v_{\mathrm{CO}} 1988$ (w), 1978 (w), 1952 (s), 1908 (m) 1668 (w) $\mathrm{cm}^{-1} .{ }^{1} \mathrm{H}$ NMR $\left(\mathrm{CD}_{3} \mathrm{CN}\right): \delta 3.94\left(\mathrm{~s}, \mathrm{CH}_{2}\right), 2.02\left(\mathrm{~s}, \mathrm{NC}(\mathrm{O}) \mathrm{CH}_{3}\right), 1.50\left(\mathrm{~d}, \mathrm{PCH}_{3}\right) .{ }^{1} \mathrm{H}$ NMR (toluene- $\left.d_{8}\right): \delta 4.01\left(\mathrm{bs}, \mathrm{CH}_{2}\right), 3.45\left(\mathrm{~s}, \mathrm{CH}_{2}\right), 1.80\left(\mathrm{~s}, \mathrm{NC}(\mathrm{O}) \mathrm{CH}_{3}\right), 1.12\left(\mathrm{~d}, \mathrm{PCH}_{3}\right) .{ }^{31} \mathrm{P} \mathrm{NMR}$ $\left(\mathrm{CD}_{3} \mathrm{CN}\right): \delta$ 25.04. FD-MS $(\mathrm{m} / \mathrm{z}): 525\left(\mathrm{M}^{+}\right)$.

\section{X-ray Crystallography}

Crystals were mounted using Paratone-N oil (Exxon) to a thin glass fiber. Data, collected at 198 K on a Siemens CCD diffractometer, were filtered to remove statistical outliers. The integration software (SAINT) was used to test for crystal decay as a bilinear function of X-ray exposure time and $\sin \theta$. The data were solved using SHELXTL by direct methods; atomic positions were deduced from an $E$ map or by an unweighted difference Fourier synthesis. $\mathrm{H}$ atom $U$ 's were assigned as $1.2 U_{\text {eq }}$ for adjacent $\mathrm{C}$ atoms. Non-H atoms were refined anisotropically. Successful convergence of the full-matrix least-squares refinement of $F^{2}$ was indicated by the maximum shift/error for the final cycle. For crystallographic data, see Table 3.

\section{Acknowledgment}

This research was supported by the National Institutes of Health. We thank Dr. Hongxiang Li for help in the early part of this project.

\section{References}

1. Lawrence JD, Li H, Rauchfuss TB, Bénard M, Rohmer M-M. Angew. Chem., Int. Ed 2001;40:17681771.

2. Lawrence JD, Li H, Rauchfuss TB. Chem. Commun 2001:1482-1483.Salyi S, Kritikos M, Åkermark B, Sun L. Chem. Eur. J 2003;9:557-560.Liu T, Wang M, Shi Z, Cui H, Dong W, Chen J, Åkermark B, Sun L. Chem. Eur. J 2004;10:4474-4479. Wang F, Wang M, Liu X, Jin K, Dong W, Li G, Åkermark B, Sun L. Chem. Commun 2005:3221-3223.Gao W, Liu J, Ma C, Weng L, Jin K, Chen C, Åkermark B, Sun L. Inorg. Chim. Acta 2006;359:1071-1080.Song L-C, Ge J-H, Zhang X-G, Liu Y, Hu Q-M. Eur. J. Inorg. Chem 2006:3204-3210.Ekstroöm J, Abrahamsson M, Olson C, Bergquist J, Kaynak FB, Eriksson L, Sun L, Becker H-C, Åkermark B, Hammarstroöm L, Ott S. Dalton Trans 2006:4599-4606. [PubMed: 17016571]Hou J, Peng X, Liu J, Gao Y, Zhao X, Gao S, Han K. Eur. J. Inorg. Chem 2006:4679-4686.Gao W, Liu J, Åkermark B, Sun L. Inorg. Chem 2006;45:9169-9171. [PubMed: 17083211]Dong W, Wang M, Liu X, Jin K, Li G, Wang F, Sun L. Chem. Commun 2006:305-307. 
3. Li H, Rauchfuss TB. J. Am. Chem. Soc 2002;124:726-727. [PubMed: 11817928]Schwartz L, Eilers G, Eriksson L, Gogoll A, Lomoth R, Ott S. Chem. Commun 2006:520-522.Song L-C, Ge J-H, Liu XF, Zhao L-Q, Hu Q-M. J. Organomet. Chem 2006;691:5701-5709.

4. Ott S, Kritikos M, Åkermark B, Sun L. Angew. Chem., Int. Ed 2003;42:3285-3288.Ott S, Borgstroöm M, Kritikos M, Lomoth R, Bergquist J, Åkermark B, Hammarstroöm L, Sun L. Inorg. Chem 2004;43:4683-4692. [PubMed: 15257597]Ott S, Kritikos M, Åkermark B, Sun L, Lomoth R. Angew. Chem., Int. Ed 2004;43:1006-1009.Sun L, Åkermark B, Ott S. Coord. Chem. Rev 2005;249:16531663.Song L-C, Tang M-Y, Su F-H, Hu Q-M. Angew. Chem., Int. Ed 2006;45:1130-1133.

5. Jiang S, Liu J, Shi Y, Wang Z, Åkermark B, Sun L. Dalton Trans 2007:896-902. [PubMed: 17297518]

6. Nicolet Y, de Lacey AL, Vernede X, Fernandez VM, Hatchikian EC, Fontecilla-Camps JC. J. Am. Chem. Soc 2001;123:1596-1601. [PubMed: 11456758]

7. Lough AJ, Park S, Ramachandran R, Morris RH. J. Am. Chem. Soc 1994;116:8356-8357.Park SH, Ramachandran R, Lough AJ, Morris RH. J. Chem. Soc., Chem. Commun 1994:2201-2202.Ayllon JA, Sayers SF, Sabo-Etienne S, Donnadieu B, Chaudret B, Clot E. Organometallics 1999;18:39813990.

8. Lee D-H, Patel BP, Clot E, Eisenstein O, Crabtree RH. Chem. Commun 1999:297-298.

9. Adams RD, Kwon OS, Miao S. Acc. Chem. Res 2005;38:183-190. [PubMed: 15766237]Tard C, Liu X, Ibrahim SK, Bruschi M, De Gioia L, Davies SC, Yang X, Wang L-S, Sawers G, Pickett CJ. Nature 2005;433:610-614. [PubMed: 15703741]

10. Seyferth D, Henderson RS, Song L-C. J. Organomet. Chem 1980;192:C1-C5.

11. King RB. J. Am. Chem. Soc 1962;84:2460.

12. Dahl LF, Wei CH. Inorg. Chem 1963;2:328-333.

13. Boehme H, Denis JP, Drechsler HJ. Liebigs Ann. Chem 1979:1447-1455.

14. Voss, J. Encyclopedia of Reagents for Organic Synthesis. Paquette, L., editor. New York: Wiley; 2004.

15. Lyon EJ, Georgakaki IP, Reibenspies JH, Darensbourg MY. J. Am. Chem. Soc 2001;123:3268-3278. [PubMed: 11457062]

16. Oki T. Top. Sterochem 1983;14:1-81.

17. Thornalley PJ. Biochem. Soc. Trans 2003;31:1343-1348. [PubMed: 14641060]

18. Seyferth D, Womack GB, Henderson RS, Cowie M, Hames BW. Organometallics 1986;5:15681575.

19. Skaugset AE, Rauchfuss TB, Wilson SR. J. Am. Chem. Soc 1992;114:8521-8526.

20. Boyke CA, van der Vlugt JI, Rauchfuss TB, Wilson SR, Zampella G, De Gioia L. J. Am. Chem. Soc 2005;127:11010-11018. [PubMed: 16076208]

21. Brandt PF, Lesch DA, Stafford PR, Rauchfuss TB. Inorg. Synth 1997;31:112. 


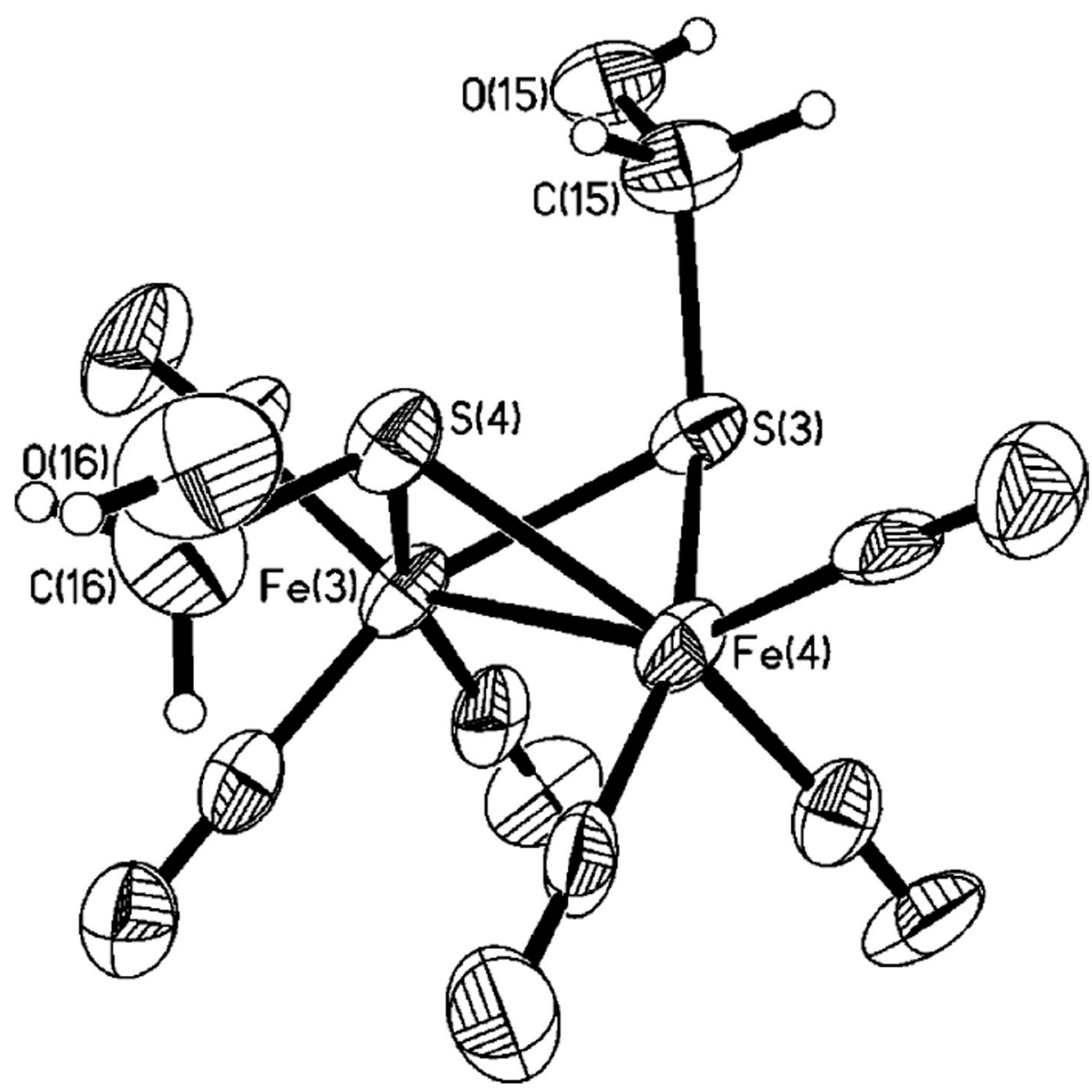

Figure 1.

Structure of one of two molecules of $\mathrm{Fe}_{2}\left(\mathrm{SCH}_{2} \mathrm{OH}\right)_{2}-(\mathrm{CO})_{6}$ in the asymmetric unit, with thermal ellipsoids drawn at the $50 \%$ probability level. 

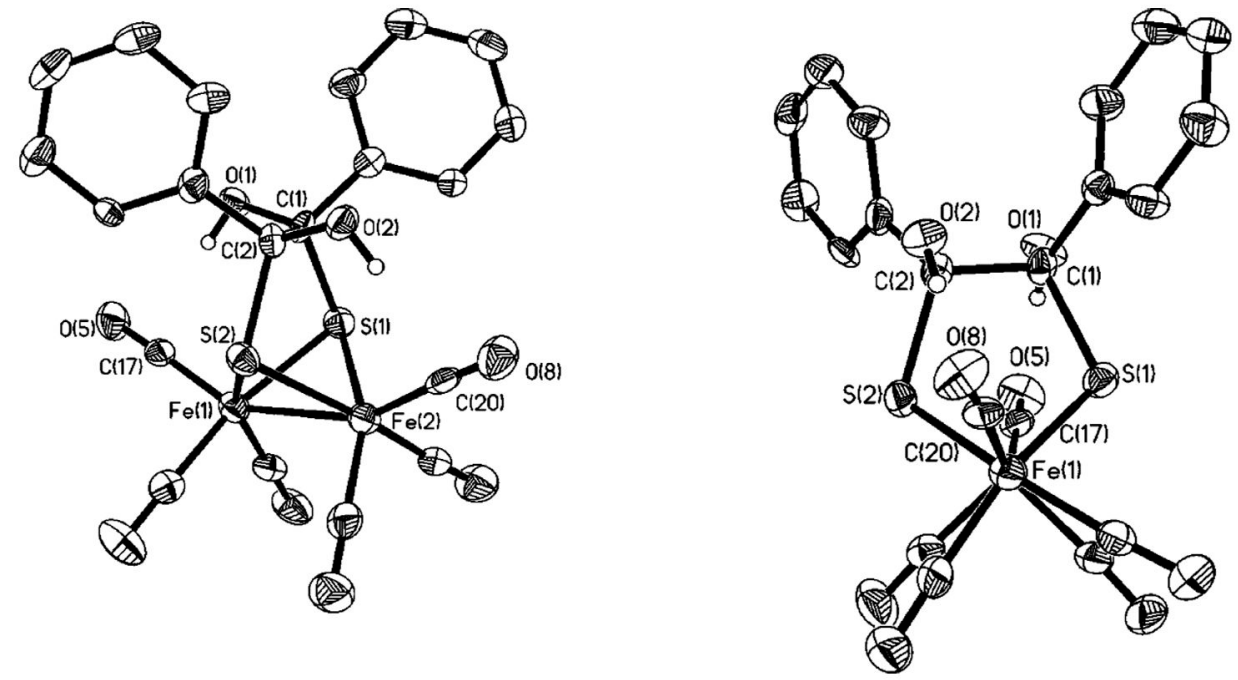

Figure 2.

Two perspectives of the structure of $\mathrm{Fe}_{2}\left[\mathrm{~S}_{2} \mathrm{C}_{2}(\mathrm{OH})_{2} \mathrm{Ph}_{2}\right](\mathrm{CO})_{6}$ with thermal ellipsoids drawn at the $50 \%$ probability level. Phenyl hydrogen atoms were omitted for clarity. 


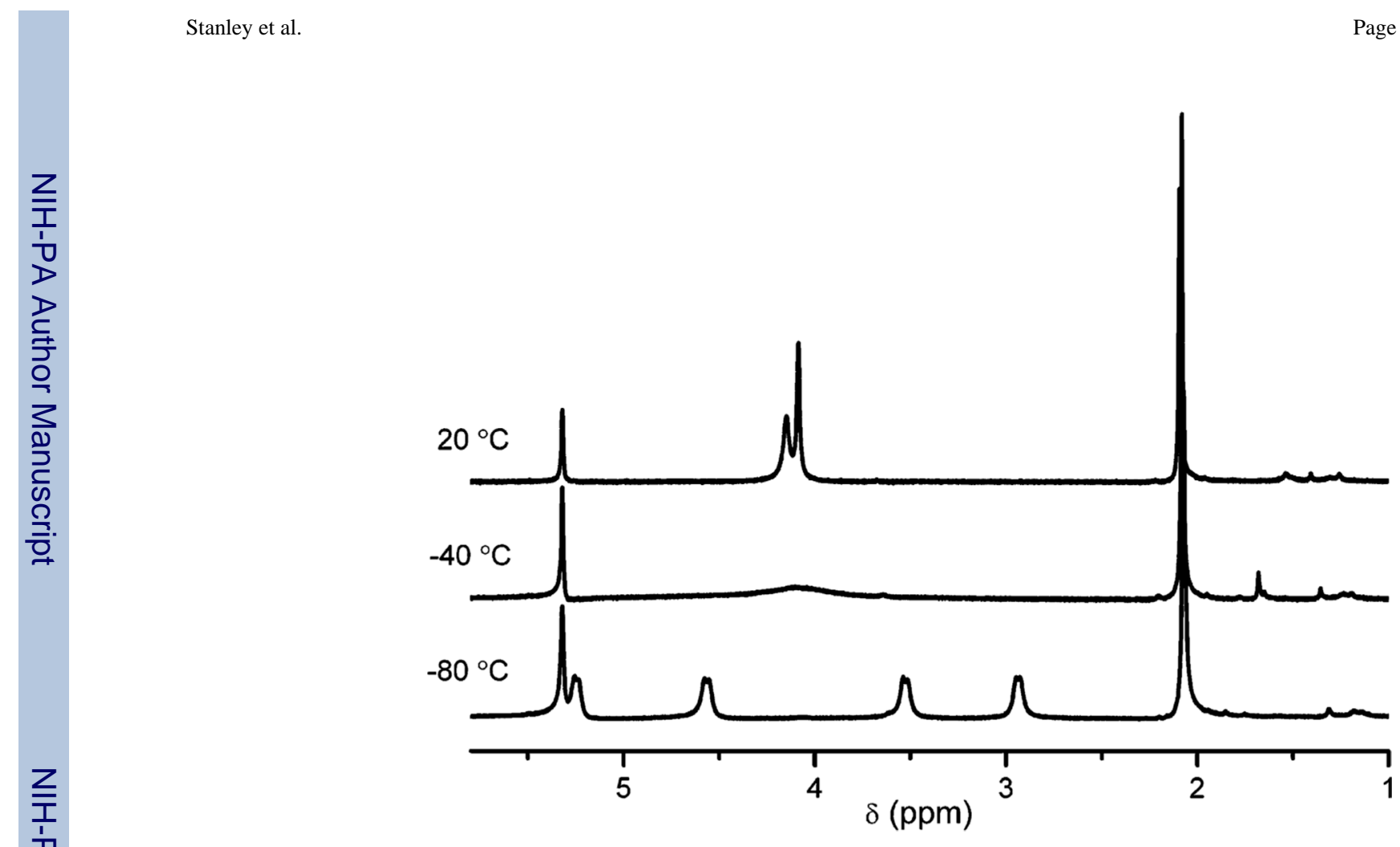

Figure 3.

$500 \mathrm{MHz}{ }^{1} \mathrm{H}$ NMR spectra of $\mathrm{Fe}_{2}\left[\left(\mathrm{SCH}_{2}\right)_{2} \mathrm{NAc}\right](\mathrm{CO})_{6}$ at various temperatures $\left(\mathrm{CD}_{2} \mathrm{Cl}_{2}\right.$ solution). 

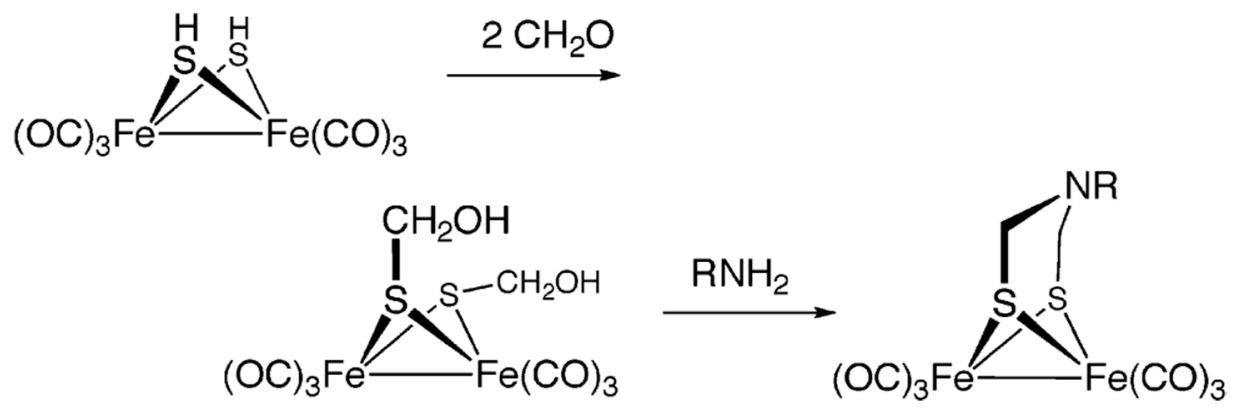

Scheme 1. 
Table 1

Selected Distances $(\AA)$ and Angles (deg) for $\left.\mathrm{Fe}_{2}\left(\mathrm{SCH}_{2} \mathrm{OH}\right)_{2} \mathrm{CO}\right)_{6}$

\begin{tabular}{llll}
\hline $\mathrm{Fe}(3)-\mathrm{Fe}(4)$ & $2.5063(14)$ & $\mathrm{C}(15)-\mathrm{S}(3)$ & $1.835(6)$ \\
$\mathrm{Fe}(3)-\mathrm{S}(3)$ & $2.260(2)$ & $\mathrm{C}(16)-\mathrm{S}(4)$ & $1.808(6)$ \\
$\mathrm{Fe}(4)-\mathrm{S}(3)$ & $2.2705(19)$ & $\mathrm{C}(15)-\mathrm{O}(15)$ & $1.403(6)$ \\
$\mathrm{Fe}(3)-\mathrm{S}(4)$ & $2.250(2)$ & $\mathrm{C}(16)-\mathrm{O}(16)$ & $1.396(6)$ \\
$\mathrm{Fe}(4)-\mathrm{S}(4)$ & $2.2577(18)$ & & \\
$\mathrm{Fe}(3)-\mathrm{S}(3)-\mathrm{Fe}(4)$ & $67.17(6)$ & $\mathrm{C}(15)-\mathrm{S}(3)-\mathrm{Fe}(4)$ & $114.3(2)$ \\
$\mathrm{Fe}(3)-\mathrm{S}(4)-\mathrm{Fe}(4)$ & $67.55(6)$ & $\mathrm{S}(4)-\mathrm{Fe}(4)-\mathrm{S}(3)$ & $80.10(6)$ \\
$\mathrm{C}(16)-\mathrm{S}(4)-\mathrm{Fe}(3)$ & $113.7(2)$ & $\mathrm{O}(15)-\mathrm{C}(15)-\mathrm{S}(3)$ & $80.47(7)$ \\
$\mathrm{C}(16)-\mathrm{S}(4)-\mathrm{Fe}(4)$ & $116.1(2)$ & $\mathrm{O}(16)-\mathrm{C}(16)-\mathrm{S}(4)$ & $108.1(4)$ \\
$\mathrm{C}(15)-\mathrm{S}(3)-\mathrm{Fe}(3)$ & $112.9(2)$ & & $109.9(4)$ \\
\end{tabular}


Table 2

Selected Distances $(\AA)$ and Angles (deg) for $\mathrm{Fe}_{2}\left[\mathrm{~S}_{2} \mathrm{C}_{2}(\mathrm{OH})_{2} \mathrm{Ph}_{2}\right](\mathrm{CO})_{6}$

\begin{tabular}{llll}
\hline $\mathrm{Fe}(1)-\mathrm{Fe}(2)$ & $2.4941(19)$ & $\mathrm{C}(1)-\mathrm{S}(1)$ & $1.866(9)$ \\
$\mathrm{Fe}(1)-\mathrm{S}(2)$ & $2.251(3)$ & $\mathrm{C}(1)-\mathrm{O}(1)$ & $1.407(9)$ \\
$\mathrm{Fe}(1)-\mathrm{S}(1)$ & $2.259(3)$ & $\mathrm{C}(2)-\mathrm{O}(2)$ & $1.393(9)$ \\
$\mathrm{Fe}(2)-\mathrm{S}(1)$ & $2.252(3)$ & $\mathrm{C}(1)-\mathrm{C}(2)$ & $1.560(12)$ \\
$\mathrm{Fe}(2)-\mathrm{S}(2)$ & $2.256(3)$ & $\mathrm{C}(17)-\mathrm{Fe}(1)$ & $1.798(10)$ \\
$\mathrm{C}(2)-\mathrm{S}(2)$ & $1.901(9)$ & $\mathrm{C}(20)-\mathrm{Fe}(2)$ & $108.4(6)$ \\
$\mathrm{Fe}(2)-\mathrm{S}(1)-\mathrm{Fe}(1)$ & $67.13(9)$ & $\mathrm{O}(1)-\mathrm{C}(1)-\mathrm{S}(1)$ & $110.1(6)$ \\
$\mathrm{Fe}(1)-\mathrm{S}(2)-\mathrm{Fe}(2)$ & $67.20(8)$ & $\mathrm{C}(2)-\mathrm{C}(1)-\mathrm{S}(1)$ & $108.0(6)$ \\
$\mathrm{S}(2)-\mathrm{Fe}(1)-\mathrm{S}(1)$ & $79.49(10)$ & $\mathrm{C}(1)-\mathrm{C}(2)-\mathrm{S}(2)$ & $99.9(3)$ \\
$\mathrm{S}(1)-\mathrm{Fe}(2)-\mathrm{S}(2)$ & $79.54(10)$ & $\mathrm{C}(20)-\mathrm{Fe}(2)-\mathrm{S}(2)$ & $110.2(3)$ \\
$\mathrm{C}(2)-\mathrm{S}(2)-\mathrm{Fe}(1)$ & $109.0(3)$ & $\mathrm{C}(20)-\mathrm{Fe}(2)-\mathrm{S}(1)$ & $108.3(3)$ \\
$\mathrm{C}(2)-\mathrm{S}(2)-\mathrm{Fe}(2)$ & $101.1(3)$ & $\mathrm{C}(1)-\mathrm{S}(1)-\mathrm{Fe}(2)$ & $102.0(3)$ \\
$\mathrm{O}(2)-\mathrm{C}(2)-\mathrm{S}(2)$ & $107.9(6)$ & & \\
\hline
\end{tabular}


Table 3

Crystallographic Data for $\mathrm{Fe}_{2}\left(\mathrm{SCH}_{2} \mathrm{OH}\right)_{2}(\mathrm{CO})_{6}$ and $\mathrm{Fe}_{2}\left[\mathrm{~S}_{2} \mathrm{C}_{2}(\mathrm{OH})_{2} \mathrm{Ph}_{2}\right](\mathrm{CO})_{6}$

\begin{tabular}{|c|c|c|}
\hline & $\mathrm{Fe}_{2}\left(\mathrm{SCH}_{2} \mathrm{OH}\right)_{2}-(\mathrm{CO})_{6}$ & $\mathrm{Fe}_{2}[\mathrm{SC}(\mathrm{OH})-\mathrm{Ph}]_{2}(\mathrm{CO})_{6}$ \\
\hline $\begin{array}{l}\text { chem formula } \\
\text { temp }(\mathrm{K}) \\
\text { cryst size }(\mathrm{mm}) \\
\text { cryst syst } \\
\text { space group } \\
a(\AA) \\
b(\AA) \\
c(\AA) \\
\alpha(\mathrm{deg}) \\
\beta(\mathrm{deg}) \\
\gamma(\mathrm{deg}) \\
V\left(\AA^{3}\right) \\
Z \\
\text { calcd density }\left(\mathrm{Mg} \mathrm{m}^{-3}\right) \\
\mu(\mathrm{Mo} \mathrm{K} \alpha)\left(\mathrm{mm}^{-1}\right) \\
\text { max/min transmissn } \\
\text { no. of measd/indep rflns } \\
\text { no. of data/restraints/params } \\
\mathrm{GOF} \text { on } F^{2} \\
R_{\text {int }} \\
\mathrm{R} 1(I>2 \sigma)(\text { all data })^{a} \\
\text { wR2 }(I>2 \sigma)(\text { all data) } b \\
\text { max peak/hole }\left(\mathrm{e} / \AA^{3}\right)\end{array}$ & $\begin{array}{l}\mathrm{C}_{8} \mathrm{H}_{6} \mathrm{Fe}_{2} \mathrm{O}_{8} \mathrm{~S}_{2} \\
193(2) \\
0.32 \times 0.32 \times 0.10 \\
\text { triclinic } \\
P \mathrm{I} \\
8.828(3) \\
12.874(5) \\
13.045(5) \\
97.935(6) \\
101.023(6) \\
94.432(6) \\
1433.1(9) \\
4 \\
1.882 \\
0.71073 \\
0.8022 / 0.3224 \\
10704 / 10355 \\
10355 / 134 / 366 \\
0.630 \\
0.0000 \\
0.0513(0.1672) \\
0.0922(0.1020) \\
1.010 /-0.827\end{array}$ & $\begin{array}{l}\mathrm{C}_{20} \mathrm{H}_{12} \mathrm{Fe}_{2} \mathrm{O}_{8} \mathrm{~S}_{2} \\
193(2) \\
0.22 \times 0.04 \times 0.02 \\
\text { monoclinic } \\
P 2_{1} / c \\
6.2738(14) \\
21.591(5) \\
16.124(4) \\
90 \\
100.483(5) \\
90 \\
2147.7(9) \\
4 \\
1.720 \\
0.71073 \\
0.9535 / 0.7797 \\
4059 / 3936 \\
3936 / 106 / 289 \\
0.949 \\
0.0000 \\
0.0829(0.2765) \\
0.0986(0.1359) \\
0.651 /-0.487\end{array}$ \\
\hline
\end{tabular}

$a_{\mathrm{RI}}=\sum\left|F_{\mathrm{O}}\right|-\left|F_{\mathrm{c}}\right| / \sum\left|F_{\mathrm{O}}\right|$

$b_{\text {wR2 }}=\left\{\sum\left[w\left(\left|F_{\mathrm{O}}\right|-\left|F_{\mathrm{C}}\right|\right)^{2}\right] / \sum\left[w F_{\mathrm{O}}^{2}\right]\right\}^{1 / 2}$, where $w=1 / \sigma^{2}\left(F_{\mathrm{O}}\right)$. 